Kamila Rezmer

Nicolaus Copernicus University

\title{
Polish Media on Religion
}

\author{
Book Review: Jacek Lindner, 12469 dróg do absolutu. Polskie media o religii \\ po 1989 roku, Wydawnictwo Adam Marszałek, Toruń 2017, pp. 414.
}

The subject of media in Poland after 1989 has been discussed in the literature on many occasions, but there are still no comprehensive studies covering religious media specific to a Polish background. The author took up this problem as one of the few, including Józef Majewski in Religia, Media, and Mitologia (2010) and Damian Guzek in Media katolickie $w$ polskim systemie medialnym (2016). All the more so due to the small number of studies on this issue, the reviewed publication - Jacek Lindner, 12,469 dróg do absolutu. Polskie media o religii po 1989 - is worth mentioning because it complements the gap in this area. The author himself says in a humorous tone that he was "born during Bierut's rule. He received education in Gdańsk and Warsaw (Polish philology and journalism) during Gomułka’s, Gierek's, Kania’s and Jaruzelski's rules. He started working in the press during the rules of the latter. He completed this stage of professional activity during the presidency of Kwaśniewski. He defended his doctorate during Kaczyński's term, and this book (i.e. 12,469 dróg do... - editor K.R.) was created during the terms of offices of presidents Komorowski and Duda. Each of the party leaders of Poland thus left his trace on its shape". He is also the author of the positions Nadzieje i porażki: dzieje prasy w woj. pomorskim po 1989 roku and Potomkowie Kulerskiego: prasa kujawsko-pomorska po 1989 roku.

Although the book is a rare attempt to analyze the issue of religious media, it faces many technical problems from the initial pages. The core of any scientific work is its research problem, which is solved in the course of the study. The author of 12,469 dróg do ... declared that "he first wrote down the subjects that dealt with and deal with the religious side of Polish citizens' lives. It was a fundamental research problem" (p. 20). Making such a census, although it is an activity necessary to determine the method of source selection and analysis, can not be treated as a research problem, because it has neither any explanatory potential, nor does it regard relationships and dependencies between entities or phenomena, or does not regard 
deviations from ideal-types (Bäcker, Rak, 2016, p. 44-53). Although the publication is about religious media, it is surprising that at the outset the author is looking for a definition of Catholic media, with one of the proposed statements by father Tadeusz Rydzyk, which can not be classified as a scientific one. The scientific definition cannot contain the language of sources. Only in the further part of the publication the author goes into the ways of defining religious media in general. However, without finding a satisfactory definition in the literature, he develops his own definition of a religious medium, cutting himself off from the "particularisms of individual factions and short-lived theological and business interests" (p. 10) - whatever they are, in this case also unclear concepts have been used. The author's definition is based on the type of sender and the amount of religious content. It distinguishes 1) one hundred percent of religious content; 2) the majority of religious content; 3) the minority of religious content (p.11). These criteria raise doubts. What does the majority mean in this case? Is it $51 \%$ or $70 \%$ of content, for example? There is no indication of the method by which one could determine what was the author's intention. In the case of scientific work, we cannot make a subjective observation, e.g. that in a given medium the majority of the place is occupied by religious content rather than by, for example, political. One has to count it, by the Berelson's method, for instance. Doubts also arise as to whether the author distinguishes the notion of religious media from the concept of Catholic press, because they are used alternately, even in the subsection devoted to the attempt of definition. He also has a tendency to identify the media with Catholicism, although one can see here the attempts to justify that such definitions can be applied to other religions (p.11), although the author himself does not make them throughout the publication. Fortunately, other media such as television, internet and radio stations are also distinguished in the remainder. What is missing the most is certainly the chapter, or at least a section devoted to methodology. True, we can find a section titled methods, although we do not read about the methods, techniques or research tools used in the study, or the methods of sources selection. What is more, the author wonders how the selection of individual titles and websites was made, which were discussed in more detail. The two criteria he indicated, which he followed while discussing particular items, are also not clear or precise. What are "phenomena typical of a particular confession" and how can one evaluate the "individuality and describe the differences that individual media entities make to similar ones" (p. 20)? These assumptions were supposed to cause that "no interesting idea to promote one's religion in the media of the Third Polish Republic did not go unnoticed" (p. 20). In the introduction, the author also states that he discussed the traditional and new media extensively. Here it is worth considering what he understands under the concept of new media. Are these social networks? If so, then the mention of Facebook and Twitter as excluded from the research field, due to the multitude of profiles contained on it, certainly is not a satisfactory explanation. At this point, the author also commits a mistake regarding classification - defining the "faceBóg" profile as an application and treating it as an "attempt of the Church's offensive" (p. 14) - as may result from an unclear statement on the subject. Only if Piotr Żyłka - a journalist and publicist, the 
founder of the "faceBóg" profile - could be treated as a representative of the entire structure of the Catholic Church? Or rather as a secular person who disseminates religious content? There are much more generalizations at work like these, e.g. when the author defines the portal as unorthodox based on just one published feuilleton, or rather its title, which it would testify to (p. 13). As for the controversial or intriguing titles themselves, it is also worth considering whether the content of the text is always in the same tone as the title. It happens that the title encourages the reader to read the article, but it turns out that it deals with trivial or non-topic problems and is not in any way revealing or interesting. However, in the reviewed publication, the problem of generalization appears many times, which we can observe in the author's enumeration and presentation of selected titles, which in his opinion indicate the nature of the journal or the views of its authors or editors. There are also statements that are not supported by any data, which are no specific assumptions but the intuitive evaluations of the author, e.g. the fact that the inhabitants of Tarnów are considered to be very religious, and yet a small number of them listen to Radio Maryja (p. 12). In the footnote to this statement we find only information that this is confirmed by the election results - that is, it is suggested that the determinant of religiosity is in this case a political standpoint of voters, and the low percentage of people listening to this particular religious station is surprising (p. 12). Another example is the statement that the region's saturation with parish newspapers is supposed to contradict the opinion about a better developed and richer so-called Poland A (p. 40). Speech is also about two new phenomena in the $21^{\text {st }}$ century, which in the author's belief are terrorism and migrations, which were to cause religious effects when media appeared (p. 37). First of all, these are not new phenomena. In history, we find many examples of them, although sometimes not explicitly named in this way. Secondly, religious effects, as the author described them, are rather a conclusion formulated on the basis of market observation, but not supported by any data, or at least a comparison with other contents that may have occurred more often at a given time. The same situation applies to the author's statement that the Church introduced concepts such as gender and natural law to the public discourse (p. 139). It seems that the term gender functioning for a long time, even in science, gained popularity in Poland rather during the discussion on the anti-violence law. At that time, politicians began to use it in the public debate, and only after did the Catholic Church. Natural law also has not gained popularity in recent years due to the Church. This concept has been known since antiquity, among others in debates on philosophy and political thought.

In order to verify the author's theorems, it would also be useful to carry out an agendasetting research and to check whether the place silence of transfer the issue between the church agenda and public agenda really took place. However, what strikes the most in the publication is the lack of a logical structure of work and coherence, for example, refers to the faithful seeking salvation, and then the topic of religion and politics appears, while the next paragraph concerns religious media in public space, until finally the author discusses the dispute of religious media with public opinion. Without any justification there is also 
a subsection devoted to popes, for example to John Paul II, or various topics ranging from the case of Lemański in the media, through bioethics, gender, liberation theology, the synod of 2015, the enthronement of Christ the King of Poland or the papal poll and even the priests' status. One can get the impression that the author has arbitrarily selected the analyzed topics. The work was to concern religious media, and we find in it a whole cross-section of topics related to the Catholic Church. The main chapters are indeed an attempt to organize such a broad material. One can also see a certain key, according to which they have been arranged, but their content covers much more than the author indicates in a few words of introduction to each of them.

In the publication, we find a lot of repetitions, even in the very beginning (p. 10) and further, such as the repeated appearance of the statement about the relationship between religion and politics (p. 121), or the thesis that "secular reality is the seat of sin [which - ed. K. R.] has served the media and other means of mass communication" (p. 131). The issue of repeatability also includes sources, e.g. recalling the same magazines. The selectivity of the author also raises the anxiety when giving examples of the phenomena he describes, which is even more suggested by his lack of scientific reliability. There is no shortage of imprecise concepts in the reviewed book, such as "intellectual criteria" used in the analysis of blogs (p. 368), "elegant cover" or the introduction of the term "paputczycy", which the author defines media devoting a lot of attention to religion, but not having religious connections (p. 105). In this case, one may wonder about the legitimacy and need to introduce this concept. When it comes to the language of work, the author is a journalist at times. There are many shortcomings of the author, unclear metaphors and colloquialisms, e.g. "priests from various camps" (p. 14), the "ease of sailing" (p.13), "the most delicate fragment of considerations" (p. 10), "enter the peaceful harbor" (p. 37) or "moral compass" (p. 223). It is also surprising that there is a large subjectivity in the selection of materials and the lack of any criteria for this selection. The author discusses these magazines which he considers the most representative and original for a given trend, while omitting theological topics. The more the researcher's attitude is puzzling, the more we realize that he deals with religious media. We find no criteria to determine which content the author defines as religious and which is already theological. Apart from selectivity in the selection of materials, another interesting phenomenon in the reviewed publication is an inconsistent way of presenting them. Once the author focuses on a few sentences on the content, then on the title, and sometimes on the technical aspects of the text, e.g. division into parts, graphic layout, "painted cover", or the publisher or any missing items.

There are no appraisals here either in the case of websites, blogs or in the case of some magazines, e.g. the author claims that the feature worthy of distinction is the cover mentioned earlier, and in the case of the seminar there is reflection on the financial aspect. It seems inappropriate to point to a given feature as being distinctive, and in other cases treating it as intriguing. In addition to the assessments, also without any justification, appear the author's views, e.g. "Web pages are edited by the same people who published or 
attractions, e.g. parish newspapers" (p. 332). Since the publication was supposed to concern religious media in general, it is only in the chapter entitled Różne ścieżki do absolutu in which a reference to other religions can be found, although in some cases it is only a short description or signaling that there was a title until the end of the $20^{\text {th }}$ century (p. 246), as well as others, such as Lutheranism, Islam, Orthodoxy or Judaism.

There was also a chapter devoted to the media critically referring to the Church and religion, but only when it comes to Catholicism. Finally, the author presents statistical data that lead to a trivial conclusion on the Polish ground that the media market is dominated by the Roman Catholic media. In addition, even in the last chapter, there are included various side threads, such as the lack of parking spaces during the Catholic Publishing Fair and the opinions of various people about this event. The main conclusion reached by the author is that "the common viewer (of religious media - K. R.) is secular".

The publication of Jacek Lindner, despite many shortcomings, certainly constitutes an interesting approach to religious media in Poland and may be a contribution to further research in this area. Certainly, it will interest people whose research area includes media studies. Noteworthy is also a rich bibliography and a CD with a list of sources attached to the publication. The author has chosen the subject which is still on the margins of media research, and certainly is extremely important in Poland, where we still have a large number of people declaring themselves as believers.

\section{References}

Bäcker, R., Rak, J. (2016.) “Problem badawczy - istota i typologie”. In Metodologia badań politologicznych. Warsaw: Polskie Towarzystwo Nauk Politycznych.

Guzek, D. (2016). Media katolickie w polskim systemie medialnym. Toruń: Wydawnictwo Adam Marszałek. Majewski, J. (2010.) Religia, Media, Mitologia. Gdańsk: słowo/obraz/terytoria.

\section{Author}

\section{Kamila Rezmer}

Nicolaus Copernicus University, Faculty of Political Science and International Studies.

Contact detail: kamila.rezmer@onet.pl 